\title{
THE EFFECT OF FREE CASH FLOW AND PROFITABILITY ON DIVIDEND PAYOUT RATIO (CASE OF LQ-45 INDEXED FIRMS IN INDONESIA STOCK EXCHANGE FOR PERIOD 2011-2018)
}

\author{
Hans Lohonauman ${ }^{1}$, Novi Swandari Budiarso ${ }^{2}$ \\ ${ }^{1,2}$ Accounting Profession Program, Economics and Business Faculty, Sam Ratulangi University, Jl. Kampus \\ Bahu, Manado, 95115, Indonesia \\ E-mail: hanz.lohonauman@gmail.com
}

\begin{abstract}
This study aims to determine the effect of free cash flow and profitability on dividend payout ratio at LQ45 Index Companies Listed on the Indonesian Stock Exchange 2011-2018. The population used in this study is the LQ45 index company listed on the Indonesian Stock Exchange in 2011-2018. The sampling method was purposive sampling according to predetermined criteria. The number of samples collected was 7 companies. The research data is secondary data obtained from the Indonesian Stock Exchange (IDX) in 2011-2018. The data that has been collected is analyzed using data analysis that first tested with classical assumptions before testing the hypothesis. Hypothesis testing in this study uses multiple linear regression analysis with the $t$ test, $f$ test, and the coefficient of determination. The result of this study indicates that free cash flow does not affect the level of dividend payout ratio. While profitability has a significant effect on dividend payout ratio. This shows that profitability affect the level of dividend payout ratio.
\end{abstract}

Keywords: free cash flow; profitability; dividend payout ratio

JEL Classification: G34, G35, M41

Article info:

Received 12 January 2021

Revised 12 January 2021

Accepted 12 January 2021

Available online 13 January 2021

\section{INTRODUCTION}

In running a business, a source of capital is needed to carry out the company's operational activities. Therefore, sources of capital are very important for a company to continue to be able to run a business and expand to develop the business of the company. This source of capital also cannot be separated from the role of a management in managing and making decisions from the source of capital. This source of capital is one of the things that determines the continuity of the operational activities of a company and is also one of the things that determines whether the company can survive or not in carrying out its operations. The capital market is one place where a company can get a source of capital. An investor to invest or invest will consider well where he will invest so that an investor needs information from the company or place where he will invest, the information required is in the form of financial statements.

Dividends are profits earned by the company and distributed to shareholders in the form of dividends. Company profits or net income generated are not always given to shareholders in the form of dividends. The profit generated can also be used by the company to be used as retained profit to be used as investment capital and capital to expand the company. This is a decision that must be made and taken from a manager where in making decisions you always have to balance the interests of the company with the interests of 
shareholders. Free cash flow describes a company's financial cash flow and is one of the factors that affect dividend policy. Cash flow owned by the company must be managed properly where one of the ways is by reducing capital expenditures in order to maintain company liquidity and company cash. Free cash flow or free cash flow represents cash owned by the company that is obtained or can be seen after the operating cash flow is reduced by capital expenditures. Profitability is the ratio used to measure a company's ability to generate profits from its normal business activities. Profitability is important for companies that are profit-oriented, which is also used to determine the success of the company, whether the company's performance is good or bad. In the case of generating profits for investors, profitability is something that must be increased by the company because profitability is the company's ability to generate profits which will later be distributed to shareholders in the form of dividends to improve the welfare of shareholders.

\section{LITERATURE REVIEW}

Financial accounting, financial report, and capital market. Martani (2012:8) defines that financial accounting is oriented towards external party reporting. With various external parties having specific objectives for each party, the preparation of financial statements uses the principles and assumptions in preparing the financial statements. Hidayat (2018) defines that financial statements are information that describes the financial condition of a company, where this information can be used as a description of a company's financial performance. The capital market has an important role in the economy of a country because the capital market carries out two functions, namely as a means of financing business or as a means for companies to obtain funds from the investor community.

Agency theory. An agency relationship is a contract in which one or more people (principal) order another person (agent) to perform a service on behalf of the principal and authorizes the agent to make the best decisions for the principal.

Free cash flow. Free cash flow describes a company's financial cash flow and is one of the factors that affect dividend policy. Murhadi (2013: 48) free cash flow is cash available in a company that can be used for various activities.

Profitability. Munawir (2014:33) defines that profitability showing the company's ability to generate profits during a certain period. This is measured by the success of the company and the company's ability to use its assets productively, thus the profitability of a company can be seen or known by comparing the profits earned in a period with the total assets or amount of the company's capital.

Dividend and dividend policy. Hanafi dan Halim (2016:361) dividends are compensation received by shareholders, in addition to capital gains. Investors will use dividends as an estimation tool regarding the company's future performance. Dividends convey management's expectations about the future. Determination of how much profit earned in a period will be distributed to shareholders in the form of dividends, and will be retained in the company in the form of retained earnings (Halim, 2015:135). The dividend payout ratio shows how much part of the net income is reinvested or retained in the company, which is believed to be useful in estimating future earnings.

Previous studies and hypothesis. Masrifah (2014), and Octaviana et al. (2019) find that free cash flow does not have a significant effect on dividend policy but inconsistent with Noviyanto (2016), and Irman et al. (2020). Budiarso et al. (2019), Madyoningrum (2019), Puspitaningtyas et al. (2019) finds that profitability has a significant effect on dividend policy.

H1: Free cash flow has a significant effect on the dividend payout ratio

$\mathrm{H} 2$ : Profitability has a significant effect on the dividend payout ratio 


\section{RESEARCH METHOD}

Types of research. The research approach used in this research is a quantitative approach which is a research method based on the positivism philosophy to examine particular population or sample, data collection with instruments, and quantitative/statistical data analysis with aim is to test predetermined hypotheses (Sugiyono, 2018:35). The method used in this research is the causal associative method.

Sample. The sample of this study is all LQ45 index listed companies in period 2011 to 2018. The sample in this study was taken using purposive sampling method. The data used in this research is quantitative data. The quantitative data in this study are obtained from audited financial reports. Sources of data in this study are secondary data, data in the form of documentation, namely financial reports obtained from the official website of the IDX.

Operational definition of variables. Free cash flow (FCF) is calculated by cash flows from operations less capital expenditures. Profitability (ROA) is measured by return on assets which calculated by ratio of net income over net assets. Dividend payout ratio (DPR) is calculated by dividend per share divided by earnings per share. follows.

Method of analysis. This study conducts multiple regressions with equation as

$$
\mathrm{DPR}=\alpha+\beta_{1} \mathrm{FCF}+\beta_{2} \mathrm{ROA}+\varepsilon
$$

This study also estimates the coefficient of determination $\left(\mathrm{R}^{2}\right)$ where value close to one means that the independent variable provides almost all the information needed to predict the variation in the dependent variable (Ghozali, 2018:97).

\section{RESULT AND DISCUSSION}

\subsection{Result}

Classic assumption test. Table 1 shows that based on the Kolmogorov-Smirnov test results from the normality test, a significance value of 0.483 (Exact Sig. (2-tailed)) is obtained where $0.483>0.05$ which indicates that the residual value has been normally distributed.

Table 1. Normality test: One-Sample Kolmogorov-Smirnov Test

\begin{tabular}{llr} 
& & Unstandardized Residual \\
\hline N & & 56 \\
Normal Parameters & Mean & 0.0000000 \\
Most Extreme Differences & Std. Deviation & 20.55378228 \\
& Absolute & 0.109 \\
& Positive & 0.097 \\
Test Statistic & Negative & -0.109 \\
Asymp. Sig. (2-tailed) & & 0.109 \\
Exact Sig. (2-tailed) & & $0.094^{\mathrm{c}}$ \\
Point Probability & & 0.483 \\
\hline a. Test distribution is Normal & & 0.000 \\
b. Calculated from data & & \\
c. Lilliefors Significance Correction & &
\end{tabular}

Table 2 shows that based on the results of the Glesjer test for heteroscedasticity test, the significance value of Free Cash Flow is $0.337>0.05$ and the profitability is a significance value of $0.171>0.05$. So it can be concluded that there is no heteroscedasticity problem in the regression model. 
Table 2. Glejser test

\begin{tabular}{|c|c|c|c|c|c|}
\hline \multirow{2}{*}{ Model } & \multicolumn{2}{|c|}{ Unstandardized Coefficients } & \multirow{2}{*}{$\begin{array}{c}\text { Standardized Coefficients } \\
\text { Beta }\end{array}$} & \multirow{2}{*}{$\mathbf{t}$} & \multirow{2}{*}{ Sig } \\
\hline & $\mathbf{B}$ & Std. Error & & & \\
\hline Constant & 12.766 & 2.584 & & 4.940 & 0.000 \\
\hline FCF & 0.145 & 0.150 & 0.134 & 0.969 & 0.337 \\
\hline ROA & 0.146 & 0.105 & 0.192 & 1.388 & 0.171 \\
\hline
\end{tabular}

Dependent Variable: ABS_Res

Table 3 shows that the results of the free cash flow tolerance value is $0.914>0.1$ and VIF value is $1.094<10$ while profitability value tolerance is $0.914>0.1$ and VIF value is 1.094 $<10$. So it can be concluded that there is no multicollinearity between the independent variable in the regression model.

Table 3. Multicollinearity test

\begin{tabular}{lcc}
\hline \multirow{2}{*}{ Model } & \multicolumn{2}{c}{ Collinearity Statistics } \\
\cline { 2 - 3 } & Tolerance & VIF \\
\hline FCF & 0.914 & 1.094 \\
ROA & 0.914 & 1.094 \\
\hline
\end{tabular}

Dependent Variable: DPR

Multiple linear regressions. Table 4 shows that free cash flow has a t-count value of $0.154<2.005$ and a significance value of $0.878>0.05$, then $\mathrm{H} 1$ is rejected because $\mathrm{t}$-count $<\mathrm{t}-$ table and a significance level of $>0.05$, this is means that free cash flow has no significant effect on the dividend payout ratio and profitability has a t-value of 4.617> 2.005 and a significance value of $0.000<0.05$, then $\mathrm{H} 2$ is accepted because $\mathrm{t}$-count $>$ is from $\mathrm{t}$-table and a significance level $<0.05$, this means that profitability has a significant effect on the dividend payout ratio. The results of data processing with multiple linear regression methods, obtained the coefficient of determination based on the adjusted $R^{2}$ value of 0.275 . So the ability of the independent variables, namely free cash flow and profitability of the dependent variable, namely the dividend payout ratio of $27.5 \%$, while the remaining $72.5 \%$ is explained by other factors that are not included in this study. Based on the results of the $\mathrm{F}$ test regression analysis, the F-count value is $11,449>3.17$ and the significance value is $0,000<0.05$. So, it can be concluded that free cash flow and profitability have a significant effect on the dividend payout ratio because F-count $>$ F-table and the level of significance $<0.05$.

Table 4. Multiple linear regression test

\begin{tabular}{|c|c|c|c|c|c|}
\hline \multirow[b]{2}{*}{ Model } & \multicolumn{2}{|c|}{ Unstandardized Coefficients } & \multirow{2}{*}{$\frac{\text { Standardized Coefficients }}{\text { Beta }}$} & \multirow[b]{2}{*}{$\mathbf{t}$} & \multirow{2}{*}{ Sig. } \\
\hline & $\mathbf{B}$ & Std. Error & & & \\
\hline Constant & 35.707 & 4.783 & & 7.466 & 0.000 \\
\hline $\mathrm{FCF}$ & -0.043 & 0.278 & -0.019 & -0.154 & 0.878 \\
\hline ROA & 0.896 & 0.194 & 0.554 & 4.617 & 0.000 \\
\hline \multicolumn{6}{|l|}{ Dependent Variable is DPR } \\
\hline $\mathrm{R}$ & 0.549 & & & & \\
\hline $\mathrm{R}$ Square & 0.302 & & & & \\
\hline Adjusted R Square & 0.275 & & & & \\
\hline Std. Error of the Estimate & 20.93800 & & & & \\
\hline $\mathrm{F}$ & $11.449 \mathrm{sign}$ & $5 \%$ & & & \\
\hline
\end{tabular}

\subsection{Discussion}

Effect of free cash flow on dividend payout ratio. Based on the test results, it is known that free cash flow has no significant effect on the dividend payout ratio, thus based on the research hypothesis $\mathrm{H} 1$ is rejected. This means that it can be concluded that partially the independent variable, namely free cash flow, has no significant effect on the dependent 
variable, namely the dividend payout ratio, because not all companies use the available free cash flow to pay dividends to investors but are used to expand their business. This finding is consistent with Masrifah (2014), and Octaviana et al. (2019) but inconsistent with Noviyanto (2016), and Irman et al. (2020).

Effect of profitability on dividend payout ratio. Based on the test results, it is known that profitability has an effect on the dividend payout ratio, thus based on the research hypothesis $\mathrm{H} 2$ is accepted. This means that it can be concluded that partially the independent variable, namely profitability, has a significant effect on the dependent variable, namely the dividend payout ratio, because profitability is the company's ability to generate profits, where profit is one of the main indicators that shows the company's ability to pay dividends. This finding is consistent with Budiarso et al. (2019), Madyoningrum (2019), and Puspitaningtyas et al. (2019).

\section{CONCLUSION}

Free cash flow has no significant effect on the dividend payout ratio, as evidenced by the results of the partial hypothesis test that has a t-count value of $-0.154<2.005$ and a significant value of $0.878>0.05$, then $\mathrm{H} 1$ is rejected. Profitability has an effect on the dividend payout ratio, as evidenced by the results of the partial hypothesis test that has a tvalue of 4.617> 2.005 and a significant value of $0.00<0.05$, then $\mathrm{H} 2$ is accepted. Based on the results, this study suggests that for companies, free cash flow research does not have a significant effect on the dividend payout ratio. This shows that management needs to pay attention to the management of capital expenditures in order to increase the distribution or payment of dividends. For investors, to get a large dividend distribution, you should buy shares or invest in the company by looking at the profits generated by the company. The further researchers need to extend the observation year, so it will be seen the consistency of the influence of the independent variables on the dividend payout ratio. Moreover, this study recommends that in further research it is necessary to add variables to see the effect of independent variables on the dividend payout ratio because in this study the level of the coefficient of determination is quite low which means there are other factors that affect the dividend payout ratio.

\section{REFERENCES}

Budiarso, N. S., Subroto, B., Sutrisno, T., \& Pontoh, W. (2019). Dividend catering, life-cycle, and policy: Evidence from Indonesia, Cogent Economics \& Finance, 7(1), 1-15. https://doi.org/10.1080/23322039.2019.1594505

Ghozali, I. (2018). Aplikasi analisis multivariate dengan program IBM SPSS 25). Semarang: Badan Penerbit Universitas Diponegoro.

Halim, A. (2015). Manajemen keuangan bisnis: konsep dan aplikasi, Edisi I. Jakarta: Mitra Wacana Media.

Hanafi, M. M., \& Halim, A. (2016). Analisis laporan keuangan, Edisi Revisi. Yogyakarta: UPP AMP YKPN

Hidayat, W. W. (2018). Pengaruh profitabilitas, leverage dan pertumbuhan penjualan terhadap penghindaran pajak: studi kasus perusahaan manufaktur di Indonesia. Jurnal Riset Manajemen dan Bisnis, 3(1), 19-26. https://doi.org/10.36226/jrmb.v3i1.82

Irman, M., Guinata, G. S., \& Diana, H. (2020). Pengaruh laba bersih, arus kas operasi, dan current ratio terhadap dividen kas pada perusahaan aneka industri yang terdaftar di Bursa Efek Indonesia periode 2015-2017. Kurs: Jurnal Akuntansi, Kewirausahaan dan 
Bisnis,

$5(1)$

24-36.

http://www.ejournal.pelitaindonesia.ac.id/ojs32/index.php/KURS/article/view/726

Madyoningrum, A. W. (2019). Pengaruh firm size, leverage dan profitabilitas terhadap kebijakan deviden. Jurnal Bisnis dan Manajemen, 6(1), 45-55. https://doi.org/10.26905/jbm.v6i1.3034

Martani, D. (2012). Akuntansi keuangan menengah berbasis PSAK. Jakarta: Salemba Empat.

Masrifah, I. (2014). Analisis hubungan laba bersih, arus kas operasi dan rups dengan dividen tunai pada industri manufaktur. Jurnal Organisasi dan Manajemen, 10(2), 113-123. https://jurnal.ut.ac.id/index.php/jom/article/view/18

Munawir, S. (2014). Analisis laporan keuangan, Edisi 4. Yogyakarta: Liberty.

Murhadi, W. R. (2013). Analisis laporan keuangan, proyeksi, dan valuasi saham. Jakarta: Salemba Empat.

Noviyanto, A. (2016). Pengaruh laba bersih, arus kas operasi, dan likuiditas terhadap kebijakan dividen. Jurnal Profita: Kajian Ilmu Akuntansi, 4(8), 1-13. http://journal.student.uny.ac.id/ojs/index.php/profita/article/view/5995

Octaviana, A. Y. C., Mardani, R. M., \& Wahono, B. (2019). Pengaruh free cash flow, profitabilitas, likuiditas, dan leverage terhadap kebijakan dividen (Studi pada perusahaan food and beverage yang terdaftar di Bursa Efek Indonesia periode 20152017). Jurnal Ilmiah Riset Manajemen, 8(18), 177-191. http://riset.unisma.ac.id/index.php/jrm/article/view/4649

Puspitaningtyas, Z., Prakoso, A., \& Masruroh, A. (2019). Pengaruh Profitabilitas Terhadap Kebijakan Dividen Dengan Likuiditas Sebagai Pemoderasi. Jurnal Administrasi Bisnis, 9(3), 1-17. https://ejournal.unsrat.ac.id/index.php/jab/article/view/25120

Sugiyono. (2018). Metode penelitian kuantitatif. Bandung: Alfabeta 